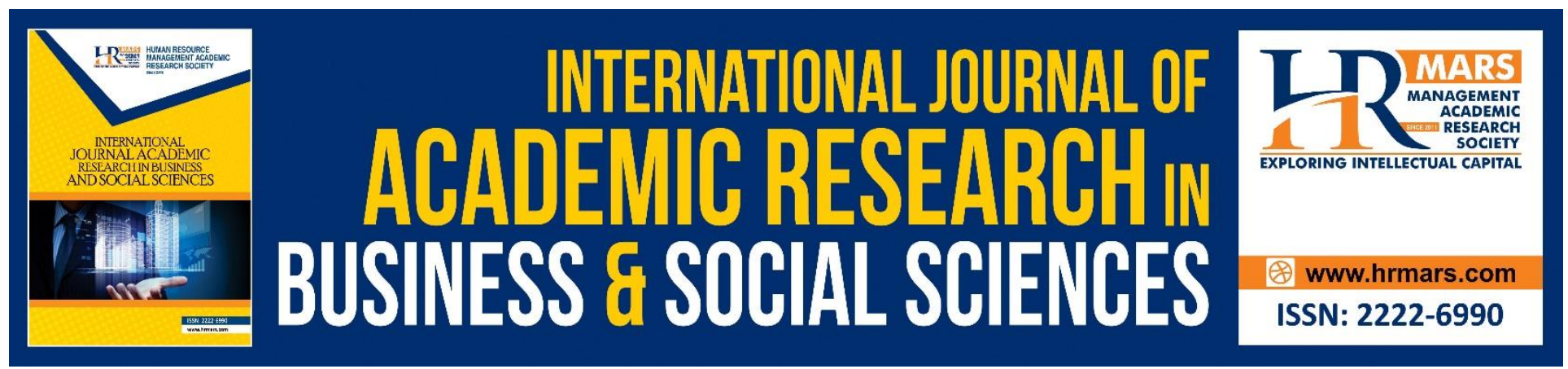

\title{
Dietary Patterns of Malaysians During the Movement Control Order (MCO) During the Covid-19 Pandemic
}

Norshariani Abd Rahman

To Link this Article: http://dx.doi.org/10.6007/IJARBSS/v10-i10/7654

DOI:10.6007/IJARBSS/v10-i10/7654

Received: 28 July 2020, Revised: 19 August 2020, Accepted: 15 September 2020

Published Online: 07 October 2020

In-Text Citation: (Abd Rahman, 2020)

To Cite this Article: Abd Rahman, N. (2020). Dietary Patterns of Malaysians During the Movement Control Order

(Mco) During The Covid-19 Pandemic. International Journal of Academic Research in Business and Social

Sciences. 10(10), 97-109.

\section{Copyright: (c) 2020 The Author(s)}

Published by Human Resource Management Academic Research Society (www.hrmars.com)

This article is published under the Creative Commons Attribution (CC BY 4.0) license. Anyone may reproduce, distribute, translate and create derivative works of this article (for both commercial and non-commercial purposes), subject to full attribution to the original publication and authors. The full terms of this license may be seen

at: http://creativecommons.org/licences/by/4.0/legalcode

$$
\text { Vol. 10, No. 10, 2020, Pg. } 97 \text { - } 109
$$

Full Terms \& Conditions of access and use can be found at http://hrmars.com/index.php/pages/detail/publication-ethics 


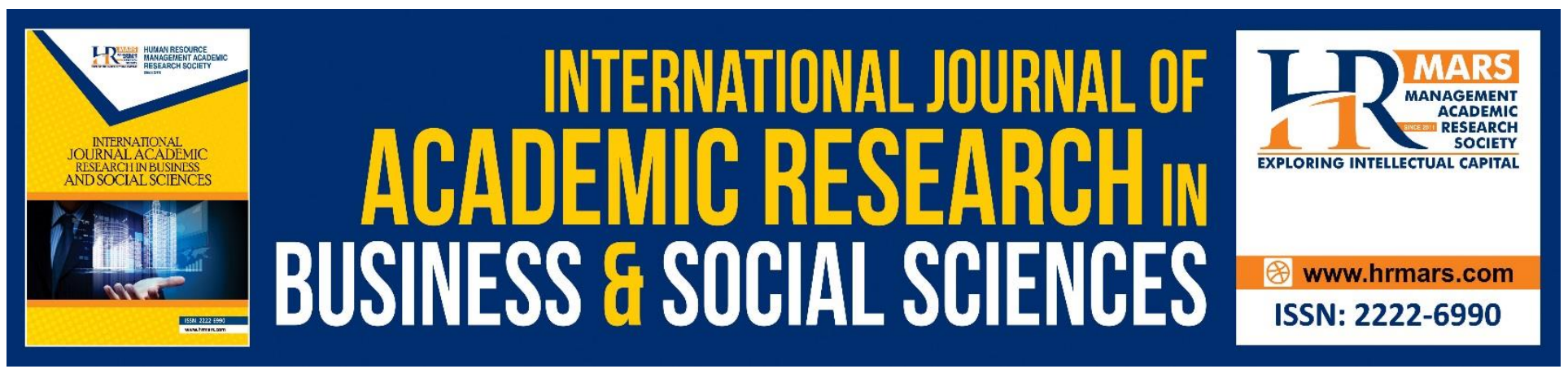

\title{
Dietary Patterns of Malaysians During the Movement Control Order (Mco) During The Covid-19 Pandemic
}

\author{
Norshariani Abd Rahman \\ Institute of Islam Hadhari, Universiti Kebangsaan Malaysia, 43600 Bangi, Selangor, Malaysia \\ Email: norshariani@ukm.edu.my
}

\begin{abstract}
The spread of the Covid-19 pandemic has resulted in the Malaysian government taking the movement control order (MCO) measure. MCO which is a partial form of lockdown influences the dietary patterns of Malaysians because of the limited movement, impact on financial planning for the income-affected communities, and the effort to maintain a healthy diet to increase immunity to fight diseases. Thus, this study investigated the dietary patterns of Malaysians during the movement control order from three aspects, namely healthy eating, frugal eating, and selection of foods with a long shelf life. This survey research used a questionnaire to collect data. Questionnaires created on Google form were distributed through the social media, namely Facebook and WhatsApp. A total of 224 respondents participated in this study. Findings showed that the respondents agreed that MCO resulted in changes in their dietary patterns. Changes in the dietary patterns of Malaysians during MCO were at the moderately high level for all three aspects of dietary pattern studied. Findings also showed that women were more concerned about healthy eating compared to men while there were no differences in dietary patterns during MCO based on employment and people's income. Hence, awareness toward nutritional education as well as preparedness in the face of pandemics need to be established among the people in Malaysia to maintain food security for the nation.
\end{abstract}

Keywords: Dietary Patterns, Food Security, Covid-19 Pandemic, Nutritional Education

\section{Introduction}

The Covid-19 pandemic has led to the government taking preventive measures through the movement control order (MCO). The Covid-19 pandemic has a major impact on human health and has resulted in life style changes through social distancing at home, physical inactivity, weight gain, behavioral addiction disorders, insufficient sunlight exposure and social isolation, and changes in food purchase (Renzo et al., 2020; Lippi et al., 2020; Batlle-Bayer et al., 2020). In addition, food consumption has also changed as a result of the lack of food stock since only a limited number of workers are allowed to work at factories and food is stuck during transit (Sharma et al., 2020). Consequently, changes in food stock will disrupt food security and affect people's nutritional intake (Niles et al., 2020; Mattioli et al., 2020). 
INTERNATIONAL JOURNAL OF ACADEMIC RESEARCH IN BUSINESS AND SOCIAL SCIENCES Vol. 10, No. 10, 2020, E-ISSN: 2222-6990 @ 2020 HRMARS

Stress can also cause eating disorders in the society. In the context of the Covid-19 pandemic, listening and reading continuously about Covid-19 from the media has put a lot of stress on the society. Stress causes a person to overeat and to consume unhealthy food containing more sugar (Arora \& Grey, 2020). This is because food containing lots of sugar can reduce stress by promoting the serotonin hormone which increases positive moods. However, these types of food give rise to the cases of obesity and cardiovascular diseases (Renzo et al., 2020).

According to the healthy lifestyle theory, life chances are primarily influenced by economic class and cultural status. However, Cockerham (2005) extended the theoretical consideration to other social structures and identities, such as living conditions, race, ethnicity, age, and gender. VanHeuvelen and VanHeuvelen (2020) in their study found that women and people living in developed nations prioritize healthy diets more than men and people who live in developing countries. A comparative study based on gender and socio-economic status in the United Kingdom revealed that during lockdowns, females were less likely to sleep within the typical range (6-9 hours) yet exercised more frequently, and people of lower socioeconomic status were associated with lower odds of sleeping within the typical range (6-9 hours), lower exercise participation, and lower consumption of fruits and vegetables (Bann et al., 2020).

Renzo et al. (2020) conducted a study to examine the impact of Covid-19 on the eating habits and lifestyle changes among the people in Italy. The findings showed that the study's respondents experienced weight gain, increased physical activities, and switched to organic food in their food and vegetable purchase. Meanwhile, a study in Spain found that the lockdown led to diet which had larger energy intake and lower nutritional quality (Batlle-Bayer et al., 2020). Nevertheless, there was limitation in the studies by Renzo et al. (2020) and Batlle-Bayer et al. (2020) in that they did not take into consideration the economic aspect of food affordability.

On the whole, it was found that past studies only concentrated on the aspect of health without focusing on the aspect of dietary pattern changes in relation to being frugal and selecting food that has longer shelf life as a result of the Covid-19 pandemic. Thus, the objectives of this study were to:

i) examine the changes in the dietary patterns of Malaysians during the MCO, namely selection of food to prevent Covid-19, selection of food to be frugal, and selection of food with a long shelf life;

ii) identify the differences in dietary patterns based on gender, type of employment and family income.

\section{Literature Review}

Food security is important in ensuring harmonious sustainability of life. Food security defined by the United Nations include food availability, accessibility, utilization, and stability (Niles et al., 2020). Food availability has shifted in the short term as a result of consumer panic shopping; however, longerterm availability challenges may also unfold. The Covid-19 pandemic threatens the accessibility of food through effects on food costs and infrastructure, including changes in food assistance distribution, public transit access, and shortages of certain products. In terms of utilization, market reports indicate widespread changes in food purchasing behaviors (Niles et al., 2020). 
INTERNATIONAL JOURNAL OF ACADEMIC RESEARCH IN BUSINESS AND SOCIAL SCIENCES Vol. 10, No. 10, 2020, E-ISSN: 2222-6990 @ 2020 HRMARS

The spread of the Covid-19 pandemic has also threatened food security as a consequence of the MCO measure taken by governments to curb the spread of this disease. As a result of the MCO, people face various difficulties in going to the grocery stores or supermarkets, resulting in the reduction of fresh food consumption such as fruits, vegetables, and fresh raw produce in the daily diet. Owing to the anxiety surrounding future food shortage, people purchase packaged and long shelf-life food rather than fresh food. These foods with long shelf-life shorten the lifeline owing to their high salt, sugar, or trans-fat content (Mattioli et al., 2020). For this reason, the consumption of processed food such as snacks, ready to eat cereals, fast food that are rich in fat, sugar and salt content will also increase (Renzo et al., 2020).

Arora and Grey (2020) argued that if the population is buying more food items, then they may be preparing more home-cooked meals. However, people need to be wise in choosing the food they want to cook. Meals may be cooked using items with fewer preservatives or additives if they are cooked at home compared to eating out. Thus, people can still obtain healthy food during the MCO if they choose their food wisely.

In understanding people's dietary patterns during the MCO, several related studies have been conducted. For example, Laguna et al. (2020) explored online food purchasing trend and their findings showed that there was an increase in trending searches related to food and shopping. Products purchased with higher frequency were pasta and vegetables (health motivations) while others were purchased to improve the buyers' mood (nuts, cheese, and chocolates). Reduced purchasing was attributed to products with a short shelf-life (fish, seafood) or because they were unhealthy and contributed to gained body weight (sugary bakery goods) or mood (desserts) (Laguna et al., 2020).

Jibri et al. (2020) looked at awareness and attitudes toward food waste, food purchase behavior and household food expenditure estimation; extent of household food waste; and willingness and information needs to reduce food waste among 284 respondents in Tunisia. The findings of this study showed that changes in consumers' food waste prevention might probably be driven more by the socioeconomical context of the Covid-19 lockdown (i.e., food availability, restricted movements, loss of income) than by a pro-environmental concern. This indicates that people's dietary patterns during MCO provide a description or notion of the food waste produced because food waste reduction has an important role for global food security.

In addition, as a result of the MCO, there are groups of people who have lost their income and jobs. Individuals who lose their jobs have to deal with concerns of unhealthy eating habits (Niles et al., 2020) as a result of their financial problems. A study by Hasni et al. (2016) found that the factors of limited food accessibility such as low income had restricted the ability of the population to obtain food.

Reducing food loss and waste are critical to achieve certain Sustainable Development Goals (SDGs), especially SDG 2 (Zero Hunger) and SDG 12 (Ensuring sustainable consumption and production patterns) (Aldaco et al., 2020). Studies have shown that several factors in households can influence food waste such as in-store behavior (over-shopping) and household management practices (poor planning/food management, storage problems) as well as psycho-social factors (personal choice and lifestyle, food habits, lack of cooking skills) (Jribi et al., 2020). Therefore, 
INTERNATIONAL JOURNAL OF ACADEMIC RESEARCH IN BUSINESS AND SOCIAL SCIENCES

Vol. 10, No. 10, 2020, E-ISSN: 2222-6990 @ 2020 HRMARS

understanding society's food selection patterns helps in planning for preparedness in facing pandemics.

\section{Research Methodology \\ Context of the Study}

This study aimed to examine the dietary patterns of Malaysians during the MCO. The dietary patterns involved three main aspects which are selection of food to prevent Covid-19, selection of food to be frugal, and selection of food that has a long shelf-life. Selection of healthy food to prevent Covid-19 in this study was based on the perception of the respondents. This study is a survey research that employed questionnaires to collect data. The questionnaires were distributed through social media such as Facebook and WhatsApp to obtain data.

\section{Respondents of the Study}

The respondents involved in this study were representatives of households. A total of 224 respondents participated in this study. Table 1 shows the details of the respondents involved in this study.

Table 1 Demographics of the Study Respondents

\begin{tabular}{llll}
\hline Background & Details & Total & Percentage (\%) \\
\hline Gender & Male & 74 & 33.0 \\
& Female & 150 & 67.0 \\
\hline \multirow{2}{*}{ Type of Employment } & Civil servants & 93 & 41.5 \\
& Private employees & 69 & 30.8 \\
& Self-employed & 62 & 27.7 \\
\hline Income & RM9,620 and above & 34 & 15.2 \\
& RM4,360 to RM9,619 & 82 & 36.6 \\
& RM 4360 and below & 108 & 48.2 \\
\hline
\end{tabular}

\section{Data Collection Procedure}

Data were obtained using a questionnaire that was developed using Google form which was then distributed through social media, namely Facebook and WhatsApp. The use of Google form is faster and simpler because data will be displayed through Excel. The questionnaire instrument was developed by the researcher herself. The Cronbach alpha obtained was high and the study instrument was considered suitable for use in this study. The Cronbach alpha values are presented in Table 2.

Table 2 Cronbach Alpha Value for the Constructs Studied

\begin{tabular}{ccc}
\hline No & Construct & Cronbach's Alpha Value \\
\hline 1 & Selection of Dietary Patterns to be Healthy & .715 \\
2 & Selection of Dietary Patterns to be Frugal & .600 \\
3 & Selection of Dietary Patterns for Long Shelf Life & .751 \\
\hline & Overall & $\mathbf{. 8 1 9}$
\end{tabular}


INTERNATIONAL JOURNAL OF ACADEMIC RESEARCH IN BUSINESS AND SOCIAL SCIENCES Vol. 10, No. 10, 2020, E-ISSN: 2222-6990 @ 2020 HRMARS

\section{Data Analysis Procedure}

Data analysis was performed using SPSS software. Data analysis for this study was divided into two which are descriptive and inferential analysis. Descriptive analysis involved mean and standard deviation while inferential analysis involved the t-test and the one-way ANOVA. To measure the dietary pattern level, mean interpretation by Nunnally (1997) was referred, as shown in Table 3.

Table 3 Interpretation of Mean Score for Dietary Pattern Constructs

\begin{tabular}{ll}
\hline Mean Score & Interpretation of Mean Score \\
\hline $1.00-2.00$ & Low \\
$2.01-3.00$ & Moderately Low \\
$3.01-4.00$ & Moderately High \\
$4.01-5.00$ & High \\
\hline
\end{tabular}

Source: Nunnally (1997)

\section{Findings of The Study}

\section{Level of Dietary Pattern Changes during MCO}

Results of the analysis presented in Table 4 show that the dietary patterns of Malaysians during the MCO was at the moderately high level for all the three aspects examined, namely aspects of pattern changes toward healthy eating to prevent Covid-19, eating to be frugal and eating products with a long shelf life. In relation to changes of healthy dietary pattern to prevent Covid 19, among the highest changes was cooking at home to maintain cleanliness to avoid Covid-19. Increasing fruit, vegetable or fresh raw vegetable intake in the daily menu and selecting nutritious food were found to be at the moderately high level while supplement or vitamin intake was at the low level.

In terms of selection of food to be frugal, cooking at home, ensuring that there was no wastage of food at home, and eating as needed were the actions highly practiced by the respondents, while ordering food online and choosing cheap food even though they lack nutrition were the actions that were scored moderately low by the respondents. Concerning selection of food with long shelflife, the respondents highly selected food that has long expiration date, followed by food stock that lasts long, frozen food and selecting less of perishable food items while the lowest was for selecting canned food. 
INTERNATIONAL JOURNAL OF ACADEMIC RESEARCH IN BUSINESS AND SOCIAL SCIENCES Vol. 10, No. 10, 2020, E-ISSN: 2222-6990 @ 2020 HRMARS

Table 4 Mean and Standard Deviation for Dietary Patterns of Malaysians during MCO

\begin{tabular}{|c|c|c|c|c|}
\hline Item & Statement & Mean & $\begin{array}{l}\text { Standard } \\
\text { Deviation }\end{array}$ & $\begin{array}{c}\text { Mean } \\
\text { Interpretation }\end{array}$ \\
\hline 1 & $\begin{array}{l}\text { I eat more fruits in my daily menu } \\
\text { to prevent Covid-19 }\end{array}$ & 3.46 & .979 & Moderately high \\
\hline 2 & $\begin{array}{l}\text { I eat more vegetables or raw } \\
\text { vegetables in my daily menu to } \\
\text { prevent Covid-19. }\end{array}$ & 3.49 & .956 & Moderately high \\
\hline 3 & $\begin{array}{l}\text { I take supplements or vitamins to } \\
\text { prevent Covid-19. }\end{array}$ & 2.96 & 1.332 & Moderately low \\
\hline 4 & $\begin{array}{l}\text { I choose nutritious food even } \\
\text { though they are more expensive. }\end{array}$ & 3.14 & 1.043 & Moderately high \\
\hline \multirow[t]{2}{*}{5} & $\begin{array}{l}\text { I cook at home to ensure } \\
\text { cleanliness. }\end{array}$ & 4.42 & .833 & High \\
\hline & $\begin{array}{l}\text { Total Selection of Healthy Dietary } \\
\text { Pattern to Prevent Covid-19 }\end{array}$ & 3.49 & .712 & Moderately high \\
\hline 6 & $\begin{array}{l}\text { I cook at home during the MCO } \\
\text { because because it saves money. }\end{array}$ & 4.24 & .973 & High \\
\hline 7 & $\begin{array}{l}\text { I order food online during the } \\
\text { MCO. }\end{array}$ & 2.33 & 1.099 & Moderately low \\
\hline 8 & $\begin{array}{l}\text { I make sure there is no wastage of } \\
\text { food at home. }\end{array}$ & 4.37 & .741 & High \\
\hline 9 & $\begin{array}{r}\text { I eat according to my needs or } \\
\text { affordability. }\end{array}$ & 4.30 & .707 & High \\
\hline \multirow[t]{2}{*}{10} & $\begin{array}{l}\text { I choose cheap food even though } \\
\text { they are not nutritious. }\end{array}$ & 2.02 & .972 & Moderately low \\
\hline & $\begin{array}{l}\text { Total Selection of Healthy Dietary } \\
\text { Pattern to be Frugal }\end{array}$ & 3.45 & .452 & Moderately high \\
\hline 11 & $\begin{array}{l}\text { I buy food stock that has a long } \\
\text { shelf life (e.g., rice vermicelli) }\end{array}$ & 3.98 & .966 & Moderately high \\
\hline 12 & $\begin{array}{l}\text { I choose to buy food that has long } \\
\text { expiration date. }\end{array}$ & 4.07 & .980 & High \\
\hline
\end{tabular}


INTERNATIONAL JOURNAL OF ACADEMIC RESEARCH IN BUSINESS AND SOCIAL SCIENCES Vol. 10, No. 10, 2020, E-ISSN: 2222-6990 @ 2020 HRMARS

\begin{tabular}{cccccc}
\hline 13 & I choose to buy frozen food. & 3.37 & .980 & Moderately high \\
14 & $\quad$ I choose to buy canned food. & 2.98 & .998 & Moderately low \\
\hline $\begin{array}{l}\text { I reduce the purchase of perishable } \\
\text { food. }\end{array}$ & 3.95 & 1.051 & Moderately high \\
\hline $\begin{array}{l}\text { Total Selection of Food Pattern } \\
\text { with a Long Shelf Life }\end{array}$ & $\mathbf{3 . 6 7}$ & $\mathbf{. 7 0 4}$ & Moderately high \\
\hline
\end{tabular}

\section{Comparison of Dietary Patterns Based on Gender}

Table 5 shows that there was a significant difference in the aspect of selection of healthy food to prevent Covid-19 based on gender $(t=-2.324, p=0.021<0.05)$. Based on the mean value, it was found that females preferred choosing a healthy diet to prevent Covid-19 compared to males. However, females and males showed the same dietary pattern selection in the aspect of selection to be frugal $(t=-1.185, p=.237>0.05)$ and selection of food with a long shelf life $(t=.211, p=.833>$ $.05)$.

Table 5 t-test for Comparison of Dietary Patterns Based on Gender

\begin{tabular}{llcrrrc}
\hline Construct & Gender & No. & Mean & $\begin{array}{c}\text { Standard } \\
\text { Deviation }\end{array}$ & t Value & $\begin{array}{c}\text { Significance } \\
\text { Level }\end{array}$ \\
\hline Healthy Eating & Male & 74 & 3.338 & .754 & -2.324 & 0.021 \\
& Female & 150 & 3.571 & .680 & & \\
\hline Frugal Eating & Male & 74 & 3.403 & .466 & -1.185 & .237 \\
& Female & 150 & 3.479 & .444 & & .833 \\
\hline Eating food that has a & Male & 74 & 3.684 & .805 & .211 & \\
long shelf life & & & & & & \\
& Female & 150 & 3.663 & .652 & & \\
\hline
\end{tabular}

\section{Comparison of Dietary Patterns Based on Income}

The findings of the one-way ANOVA test showed that there were no significant difference in the dietary patterns during MCO based on income for the three aspects examined, namely healthy eating, frugal eating and eating food that has a long shelf life. A summary of the findings is presented in Table 6. 
INTERNATIONAL JOURNAL OF ACADEMIC RESEARCH IN BUSINESS AND SOCIAL SCIENCES Vol. 10, No. 10, 2020, E-ISSN: 2222-6990 @ 2020 HRMARS

Table 6 One-Way ANOVA Comparison for Dietary Patterns Based on Income

\begin{tabular}{|c|c|c|c|c|c|c|}
\hline Constructs & & $\begin{array}{c}\text { Total Sum } \\
\text { of } \\
\text { Squares }\end{array}$ & $\begin{array}{l}\text { Degrees of } \\
\text { Freedom }\end{array}$ & $\begin{array}{l}\text { Mean } \\
\text { Square }\end{array}$ & $\mathrm{F}$ & $\begin{array}{c}\text { Significance } \\
\text { Level }\end{array}$ \\
\hline & Between Group & 2.414 & 2 & 1.207 & 2.410 & .092 \\
\hline \multirow{2}{*}{$\begin{array}{l}\text { Healthy } \\
\text { Eating }\end{array}$} & Within Group & 110.697 & 221 & .501 & & \\
\hline & Total & 113.111 & 223 & & & \\
\hline \multirow[t]{4}{*}{ Frugal Eating } & Between Group & .370 & 2 & .185 & .907 & .405 \\
\hline & Within Group & 45.147 & 221 & .204 & & \\
\hline & Total & 45.517 & 223 & & & \\
\hline & Between Group & .576 & 2 & .288 & .578 & .562 \\
\hline $\begin{array}{l}\text { Eating food } \\
\text { that has a } \\
\text { long shelf life }\end{array}$ & Within Group & 110.018 & 221 & .498 & & \\
\hline & Total & 110.594 & 223 & & & \\
\hline
\end{tabular}

\section{Comparison of Dietary Patterns Based on Employment}

Findings of the one-way ANOVA test showed that there was no significant difference in dietary patterns during MCO based on employment for all three aspects studies, namely healthy eating, frugal eating and eating food that has a long shelf life as presented in Table 7.

Table 7 One-Way ANOVA Test for Comparison of Dietary Patterns Based on Employment

\begin{tabular}{|c|c|c|c|c|c|c|}
\hline Construct & & $\begin{array}{c}\text { Total Sum } \\
\text { of } \\
\text { Squares }\end{array}$ & $\begin{array}{l}\text { Degrees of } \\
\text { Freedom }\end{array}$ & $\begin{array}{l}\text { Mean } \\
\text { Square }\end{array}$ & $\mathrm{F}$ & $\begin{array}{c}\text { Significance } \\
\text { Level }\end{array}$ \\
\hline & Between Group & 2.212 & 2 & 1.106 & 2.204 & .113 \\
\hline \multirow{2}{*}{$\begin{array}{l}\text { Healthy } \\
\text { Eating }\end{array}$} & Within Group & 110.899 & 221 & .502 & & \\
\hline & Total & 113.111 & 223 & & & \\
\hline \multirow[t]{4}{*}{ Frugal Eating } & Between Group & .771 & 2 & .385 & 1.904 & .151 \\
\hline & Within Group & 44.746 & 221 & .202 & & \\
\hline & Total & 45.517 & 223 & & & \\
\hline & Between Group & .714 & 2 & .357 & .718 & .489 \\
\hline \multirow[t]{2}{*}{$\begin{array}{l}\text { Eating food } \\
\text { that has a } \\
\text { long shelf life }\end{array}$} & Within Group & 109.879 & 221 & .497 & & \\
\hline & Total & 110.594 & 223 & & & \\
\hline
\end{tabular}

\section{Discussion}

Overall, the findings showed that in addition to prioritizing healthy food, Malaysians were smart in planning for sustainability of food supply. Based on the findings of this study, most Malaysians cook their own food because this guarantees cleanliness and at the same time allow them to be frugal 
INTERNATIONAL JOURNAL OF ACADEMIC RESEARCH IN BUSINESS AND SOCIAL SCIENCES Vol. 10, No. 10, 2020, E-ISSN: 2222-6990 @ 2020 HRMARS

even though there are online food ordering services. The same trend can also be seen in a study conducted in Poland where $62.3 \%$ of the study's respondents chose to cook their own food during quarantine (Sidor \& Rzymski, 2020). If studied in depth, the factors that helped the survival of Malaysians in obtaining food was the assistance from the government and donations from the local communities in the form of financial or food aid for the affected people. Thus, the findings show that there were no differences in the selection of dietary patterns based on employment and income among Malaysians even though there are groups of people whose income was affected as a result of the MCO. In Malaysia, stores that supply food were also allowed to operate as usual during the MCO to ensure adequate food supply for the people. In addition, the provision of internet not only helped in education but also assisted Malaysians who wanted to obtain food online or carry out online business. The initiatives implemented by the government of Malaysia helped ensure the sustainability of food supply for the people.

Even though the findings of this study showed that purchase of online food was moderately low, raw ingredients purchased for cooking increased during the MCO because online grocery shopping can offer interesting benefits to customers, including time savings, home delivery and, in the COVID-19 context, social distancing. The findings of the study by Jbiri et al. (2020) in Tunisia were in contrast to the situation in Malaysia where the findings of Jbiri et al. found that $66 \%$ of the people bought items at the supermarkets and only $2.1 \%$ of the respondents used home delivery service. However, an effect of online purchases is that it will result in an increase in packaging materials (Sharma et al., 2020). This is further exacerbated when recycling activities are also limited during MCO (Sharma et al., 2020). Nonetheless, food items that last long are usually sold in cans or recyclable plastic. For this reason, Malaysians need to be wise in managing food packaging waste so as not to pollute the environment.

The findings of this study showed that women were more concerned about consumption of healthy food in the effort to prevent Covid-19 compared to men. This is because women play an important role in providing food for the family particularly those who are married (McNamara \& Wood, 2019; VanHeuvelen \& VanHeuvelen, 2020). Moreover, previous studies have shown that women have more preference toward healthy diets compared to men such as having the tendency to eat fresh fruits and vegetables more frequently (VanHeuvelen \& VanHeuvelen, 2020; Cockerham, 2005). This is because women tend to control their body weight more, wanting an ideal body size, and as a result, they are more likely to choose healthier food compared to men (VanHeuvelen \& VanHeuvelen, 2020). However, a study by Sidor and Rzymski (2020) found that food consumption in Poland was not influenced by gender.

The findings of this study showed that the selection of healthy food such as fruits and vegetables was at the moderately high level even though past studies found that a diet poor in fruit and vegetables is frequent during isolation. The intake of fruits and vegetables that contain lots of vitamins is important because vitamins have recently been identified as a principal weapon in the fight against the Covid-19 virus (Mattioli et al., 2020). However, the cases of obesity during MCO should be addressed because coronavirus infection does not differ as obese patients have been associated with a higher risk of morbidity and mortality (Cherikh et al., 2020). A study by Rolland et al. (2020) showed that food caloric intake increased by $30 \%$ during the lockdown in France. In 
INTERNATIONAL JOURNAL OF ACADEMIC RESEARCH IN BUSINESS AND SOCIAL SCIENCES Vol. 10, No. 10, 2020, E-ISSN: 2222-6990 @ 2020 HRMARS

addition, Rundle et al. (2020) also found that lockdowns are predicted to increase childhood obesity levels. Thus, selection of dietary patterns by the society helps in sustainability of food and food security that is supportive of the SDGs.

\section{Conclusion}

This study analyzed the selection of dietary pattern during MCO among Malaysians. The dietary patterns studied included selection of food to be healthy, to be frugal and food that has a long shelf life. The findings showed that selection of dietary patterns for all three aspects studied was at a moderately high level. Comparison of dietary patterns based on gender indicated that women had more tendency to choose healthy food in the effort to prevent Covid-19 compared to men. However, there was no significant difference found in the dietary patterns of Malaysians based on income and type of employment. The findings indicate that Malaysians were still able to obtain healthy food that is affordable and has a long shelf life even though their movements were restricted. This is because the Malaysian government continued to provide assistance to the people whose income was affected and offered moratoriums to ensure the survival of the people in obtaining food.

Therefore, Malaysians need to be wise in selecting dietary patterns even though their movements are limited, their income affected, and changes had to be made to their lifestyle during MCO. The findings of this study show that nutrition education needs to be given to Malaysians so that the people would choose healthy and safe food. Dissemination of information regarding nutrition and dietary education through the mass media and social media is capable of educating the society so that they are concerned about their food choices. Food aid given by the government and non-governmental organizations (NGOs) as well as private aid to the communities affected should take into consideration food nutrition and shelf life of food for the long term. The recent situation faced by Malaysians during the MCO in curbing the spread of the Covid-19 pandemic has raised awareness among the people to choose food that is healthy for their family even though they selected food with a long shelf life such as canned food and cooked at home for the family. Thus, proactive strategies are needed in dealing with food insecurity while facing a crisis (Aldaco et al., 2020; Handu et al., 2020).

In order to sustain food security, keeping foods that are good sources of immuno-supportive nutrients, planning times to eat meals, portions and having a cut-off time for eating but mostly having in mind positive attitudes could be helpful to tackle the negative health effects of quarantine (Muscogiuri et al., 2020). Batlle-Bayer et al. (2020) suggested that strategies are established to ensure sustainable food habits in the future, including those occurring in a possible future lockdown, such as designing short sustainable food production and consumption guidelines. Hence, this study on the dietary patterns of Malaysians during MCO as a result of Covid-19 can provide planning information concerning food sustainability and food security to the government as a form of preparedness in facing pandemics. Nevertheless, the limitation of this study in relation to the method of data gathering in which data were only obtained from questionnaires can be improved in future studies by taking into account data from respondent interviews to gather a more comprehensive understanding. 
INTERNATIONAL JOURNAL OF ACADEMIC RESEARCH IN BUSINESS AND SOCIAL SCIENCES

Vol. 10, No. 10, 2020, E-ISSN: 2222-6990 @ 2020 HRMARS

\section{Acknowledgement}

This article was funded by the research grant DPP-2018-001, Universiti Kebangsaan Malaysia.

\section{References}

Aldaco, R., Hoehn, D., Laso, J., Margallo, M., Ruiz-Salmón, J., Cristobal, J.,Vazquez-Rowe, I. (2020). Food waste management during the COVID-19 outbreak: a holistic climate, economic and nutritional approach. Science of the Total Environment, 742, 140524. https://doi.org/10.1016/j.scitotenv.2020.140524.

Arora, T., \& Grey, I. (2020). Health behaviour changes during COVID-19 and the potential consequences: A mini-review. Journal of Health Psychology, 25(9), 1155-1163. https://doi.org/10.1177/1359105320937053

Bann, D., Villadsen, A., Maddock, J., Hughes, A., Ploubidis, G., Silverwood, R., Patalay. P. (2020). Changes in the behavioural determinants of health during the coronavirus (COVID-19) pandemic: gender, socioeconomic and ethnic inequalities in 5 British cohort studies. Health Evaluation and Promotion, 47(1), 248-250. https://doi.org/10.7143/jhep.47.248

Batlle-Bayer, L., Aldaco, R., Bala, A., Puig, R., Laso, J., Margallo, M., Fullana-i-Palmer, P. (2020). Environmental and nutritional impacts of dietary changes in Spain during the COVID-19 lockdown. Science of The Total Environment, 748, 141410.

https://doi.org/10.1016/j.scitotenv.2020.141410

Cherikh, F., Frey, S., Bel, C., Attanasi, G., Alifano, M., \& Iannelli, A. (2020). Behavioral Food Addiction During Lockdown: Time for Awareness, Time to Prepare the Aftermath. Obesity Surgery, 30(9), 3585-3587. https://doi.org/10.1007/s11695-020-04649-3

Cockerham, W. C. (2005). Health Lifestyle Theory and the Convergence of Agency and Structure. Journal of Health and Social Behavior 46 (1):51-67.

Handu, D., Moloney, L., Rozga, M., \& Cheng, F. W. (2020). Malnutrition Care During the COVID-19 Pandemic: Considerations for Registered Dietitian Nutritionists. Journal of the Academy of Nutrition and Dietetics. https://doi.org/10.1016/j.jand.2020.05.012.

Hasni, N. H., Omar, M., Haim, S. A., Ghazali, N. (2016). Food Security Threats Against Community Lanoh: Case Study in Kampung Air Bah, Lenggong, Perak. Journal of Social Sciences and Humanities, Special Issue 2 (October 2016): 143-159

Jribi, S., Ben Ismail, H., Doggui, D., \& Debbabi, H. (2020). COVID-19 virus outbreak lockdown: What impacts on household food wastage? Environment, Development and Sustainability, 22(5), 3939-3955. https://doi.org/10.1007/s10668-020-00740-y

Laguna, L., Fiszman, S., Puerta, P., Chaya, C., \& Tarrega, A. (2020). The impact of COVID-19 lockdown on food priorities. Results from a preliminary study using social media and an online survey with Spanish consumers. Food Quality and Preference, 86, 104028.

https://doi.org/10.1016/j.foodqual.2020.104028.

Lippi, G., Henry, B. M., Bovo, C., \& Sanchis-Gomar, F. (2020). Health risks and potential remedies during prolonged lockdowns for coronavirus disease 2019 (COVID-19). Diagnosis (Berlin, Germany), 7(2), 85-90. https://doi.org/10.1515/dx-2020-0041.

Mattioli, A. V., Sciomer, S., Cocchi, C., Maffei, S., \& Gallina, S. (2020). "Quarantine during COVID-19 outbreak: Changes in diet and physical activity increase the risk of cardiovascular disease." Nutrition, Metabolism and Cardiovascular Diseases, (Article in Press). https://doi.org/10.1016/j.numecd.2020.05.020. 
INTERNATIONAL JOURNAL OF ACADEMIC RESEARCH IN BUSINESS AND SOCIAL SCIENCES

Vol. 10, No. 10, 2020, E-ISSN: 2222-6990 @ 2020 HRMARS

McNamara, K., \& Wood, E. (2019). Food taboos, health beliefs, and gender: understanding household food choice and nutrition in rural Tajikistan. Journal of Health, Population, and Nutrition, 38(1), 17. https://doi.org/10.1186/s41043-019-0170-8

Muscogiuri, G., Barrea, L., Savastano, S., \& Colao, A. (2020). Nutritional recommendations for COVID19 quarantine. European Journal of Clinical Nutrition, 74(6), 850-851. https://doi.org/10.1038/s41430-020-0635-2.

Niles, M. T., Bertmann, F., Belarmino, E. H., Wentworth, T., Biehl, E., \& Neff, R. (2020). The early food insecurity impacts of covid-19. Nutrients, 12(7), 1-23. https://doi.org/10.3390/nu12072096.

Renzo, L. D., Gualtieri, P., Pivari, F., Soldati, L., Attina, A., Cinelli, G. De Lorenzo, A. (2020). Eating habits and lifestyle changes during COVID-19 lockdown: An Italian survey. Journal of Translational Medicine, 18(1), 1-15. https://doi.org/10.1186/s12967-020-02399-5.

Rolland, B., Haesebaert, F., Zante, E., Benyamina, A., Haesebaert, J., \& Franck, N. (2020). Global changes and factors of increase in caloric food, screen and substance use during the early COVID19 containment phase in France: a general population online survey. Journal of Medical Internet Research (June). https://doi.org/10.2196/preprints.19630.

Rundle, A. G., Park, Y., Herbstman, J. B. (2020) COVID-19 related school closings and risk of weight gain among children. Obesity 28 (6): 1008-1009.

Sharma, H. B., Vanapalli, K. R., Cheela, V. S., Ranjan, V. P., Jaglan, A. K., Dubey, B., Bhattacharya, J. (2020). Challenges, opportunities, and innovations for effective solid waste management during and post COVID-19 pandemic. Resources, Conservation and Recycling, 162, 105052. https://doi.org/10.1016/j.resconrec.2020.105052.

Sidor, A., \& Rzymski, P. (2020). Dietary choices and habits during COVID-19 lockdown: Experience from Poland. Nutrients, 12(6), 1-13. https://doi.org/10.3390/nu12061657.

VanHeuvelen, T., \& VanHeuvelen, J. S. (2019). The (Economic) Development of Healthy eating Habits. Sociology of Development, 5(1), 91-113. https://doi.org/10.1525/sod.2019.5.1.91 